\title{
Analysis of Manufacturing Transfer Characteristics Based on Global Value Chain Reconstruction
}

\author{
Jingyi $\mathrm{YAN}^{1, \mathrm{a}^{*}}$, Jian $\mathrm{MIN}^{2, \mathrm{~b}}$ \\ ${ }^{1}$ Nanhu campus of Wuhan university of technology, Wuhan city, \\ Hubei province, the People's Republic of China \\ ${ }^{2}$ College of management of Wuhan university of technology, Wuhan city, \\ Hubei province, the People's Republic of China \\ a171929614@qq.com, b20431622@qq.com \\ *Jingyi Yan
}

Keywords: global value chain restructuring, manufacturing, transfer

\begin{abstract}
Manufacturing is the backbone of an economy. Based on the background of global value chain reconstruction, this paper studies the transfer characteristics of manufacturing industry from the aspects of industrial layout transfer, structure transfer, division of labor transfer and capital flow transfer, hoping to provide help for Chinese manufacturing enterprises to go abroad and move to the end of high value-added value of the value chain.
\end{abstract}

\section{Introduction}

Against the background of economic globalization, international industries are constantly shifting and the international division of labor is deepening. The structure of global value chain is undergoing subtle changes and restructuring: Developing countries continue to move up the global value chain through innovation, and developed countries are committed to "reindustrialization" to pursue the development of the real economy. The manufacturing sector has become the commanding height of global industrial competition. It has also become an important force for countries to cope with the sluggish economic recovery after the financial crisis and promote the shift of drivers from old to new.

\section{Characteristics of manufacturing industry layout under the background of global value chain reconstruction}

\subsection{Manufacturing production layout changes}

With the development of modern logistics, transportation and communication technology, the global value chain structure of transnational corporations is gradually changing from the "center-periphery" offshore production layout with the domestic market as the primary one to the offshore production layout with the host as the core market. During the 2008 financial crisis, international trade fell much faster than global GDP. The problems of the crisis, such as credit constraints, reduced demand and the risk of insufficient liquidity, have forced multinationals to rethink their resilience. With the support of modern logistics technology, production no longer follows the principle of lowest cost or close to the origin of raw materials, but has two trends: one is to place production and assembly closer to the home market in order to shorten the supply chain, increase the control of production and reduce the impact of external shocks; The other direction is to bring production and service closer to customers, so that multinational enterprises can respond to customers' demands through more agile supply speed and stronger customization ability, so as to enhance the elasticity of supply chain. For example, some American enterprises have transferred their production links to Mexico, Canada and other regions closer to the domestic market, effectively reducing the response time and logistics costs. 
Due to the emergence of middle-income groups, China has become the world's second largest consumer market after the United States, and China's neighboring countries and regions have gradually become the focus of production layout. Meanwhile, the "One Belt and One Road" policy has also increased the strategic investment of Chinese enterprises in southeast Asia and some African countries. This part of the country relative to the developed countries, however, political and economic environment, the stability is relatively low, the host country regime change, factors such as political system transformation, it is easy to cause a government default, the new government came to power tend to stop the previous government signed and has been implemented in the contract or agreement, cause the enterprise funds recovery in sight, the expansion of financial risks.

\subsection{Reindustrialization of developed countries}

After the 2008 financial crisis, the real economy once again attracted the attention of developed countries. Return to promote manufacturing, Europe and the United States and other developed countries started to enact relevant laws and regulations, and set up relevant organizations, such as the United States introduced the manufacturing enhancement act, the U.S. manufacturing revitalization act, European countries are also issued in succession law regulations, including "the Europe 2020 strategy", the German high technology strategy 2020, Britain's "growth as the goal of innovation and research strategy", etc. GE, for example, is building new high-density battery plants in New York and Texas, and has eliminated capacity it used to outsource to China. Under the background of the return of the manufacturing industry in developed countries, China is faced with the dilemma of relatively insufficient input in the manufacturing industry and a continuous decline in the international market, which adversely affects the export and employment of the manufacturing industry.

Developed countries in the process of industrialization inevitably appeared again the rise of trade protectionism, the export enterprises suffered fromincreases in the number of anti-dumping lawsuits, and our country enterprise is in line with the globalization process is relatively short, often difficult to win, and further stimulate foreign enterprises to China's export products more anti-dumping complaints, causing a vicious cycle. In addition, many developed countries use the name of "green" to protect trade. The relevant regulations and standards of "green" barriers are flexible and wide-ranging, involving all industrial products and links, laws, degrees, labor standards and other aspects. Export products are mainly faced with the following three situations: being rejected by the host country; be recalled by the host country; increasing costs to meet the standards required by the host country. No matter which of the above situations occurs, it will certainly require the enterprise to further increase the investment capital before it recovers the funds invested in the previous stage, which is worse for the enterprise which is not particularly sufficient in capital itself and urgently needs to alleviate the shortage of capital through sales revenue. In addition, product recall and other actions will reduce the image of the enterprise, further affect the financing behavior of the enterprise from other channels, and expand the financial risk.

\subsection{Industries in emerging economies to undertake}

Emerging countries, which used to act as processing plants in global value chains, are now moving to high-end manufacturing and consumer markets. On the one hand, emerging economies, represented by China and India, are paying more and more attention to the investment and development of science and technology, actively carrying out the optimization, transformation and upgrading of industrial structure, and moving towards the high value-added fields of global value chain. On the other hand, some emerging countries have gradually grasped the opportunity of the international flow of production factors to improve the economic and trade environment, which not only improves the quality of labor force, but also has obvious advantages over China in labor cost. More and more multinational companies have started to transfer contract manufacturing to these countries. Some labor-intensive and capital-intensive industries in China also have such a transfer trend. In 2012, the working-age population in China fell for the first time since the reform and opening up, 
which led to the increase of labor costs in China. From 2008 to 2015, the minimum wage in coastal areas, central regions, southwest regions and northwest regions increased year by year. At the same time, with the rising prices of water, electricity, natural gas and other energy sources, the production and sales costs of enterprises are rising rapidly, which weakens the foundation on which labor-intensive industries rely for survival and profits. In addition, the appreciation trend of the RMB against the us dollar is obvious. From 2003 to 2016 , the RMB has appreciated by $23.26 \%$ in total, which not only caused the decline of the competitiveness of China's export products, but also directly caused the exchange loss of the appreciation of the RMB against the us dollar.

\section{Transfer Characteristics of Manufacturing Structure Under the Background of Global Value Chain Reconstruction}

\subsection{Technology innovation and diffusion effect of high-tech industry}

Technological innovation is essentially the integration, excavation and recreation of knowledge. In the traditional environment, due to the existence of information exchange barriers, manufacturers have limited channel resources, so their partners are relatively fixed. Exchange of information between manufacturing enterprises in the Internet environment barrier is broken, greatly shorten the knowledge dissemination of time, cost, the enterprise can through the Internet looking for partners in the field of research and development design, cooperation can be more diversified, so as to make the enterprise production activities of research and development design behavior are not isolated, increase the chances of the collision and fusion of heterogeneous knowledge, promote the technology innovation. In addition, the improvement of infrastructure further promotes the progress of technology and the improvement of efficiency. Bingxia Liu (2010) pointed out that the development and improvement of infrastructure is conducive to the promotion and expansion of regional exchanges of personnel and goods, so as to promote the spread of knowledge and technology. With the development of economy, industrial clusters gradually increase, and provide a broad platform for the diffusion of technology. Yaowu Sun and Deming Zeng pointed out that the study, knowledge transfer, technological innovation and spillover as well as network effect in high-tech industrial clusters can promote the generation, update and diffusion of technical standards. Industrial clusters will also bring talents, capital, knowledge, information and technology together within a certain range, which is conducive to extensive and frequent exchanges among enterprises in the gathering area, so as to improve the cognition ability of enterprises in the gathering area to new technologies, digestion and absorption ability, and then accelerate the diffusion of regional technological innovation achievements.

High and new technology has the characteristics of fast updating and high human resources requirements. In the process of acquiring the latest knowledge and technology, enterprises need to spend a lot of capital. In order to achieve the purpose of continuous innovation, enterprises need long-term and continuous investment in research and development. In the process of obtaining long-term funds, enterprises often face the problem of asset mortgage. Once the innovation and development fails, enterprises will lose a large amount of principal. Banks, however, lack the incentive to provide capital for innovative enterprises with mismatched returns and risks. Financial institutions in different countries and regions have different restrictions on borrowing, which is likely to cause financing difficulties for enterprises and thus financial risks.

\subsection{Global manufacturing cluster effect}

The division of labor of global value chain catalyzes the cluster of manufacturing industry. Jun Liu and others pointed out that "Internet + " promoted the aggregation of industries through labor sharing and knowledge spillover. The Internet has greatly improved the efficiency of information, making the communication within and between industries faster and more accurate, allowing knowledge to be transferred more quickly and accelerating the industry gathering. Emerging economies in the process of integration into the global value chain established a large number of industry cluster, although part of the industrial cluster 
unable to break through the muzzle of developed countries and multinational companies in the development bottleneck, but there are still a part of the industrial cluster under the help of modern communication technology at home and abroad engaged in technical training and marketing communication, access, absorption and transformation of the latest knowledge and technology, has realized the low added value in the global value chain link to high value-added links to move, change the industrial structure.

Enterprises in industrial clusters can get help from external economy, learning and innovation platform, factor resource attraction and other aspects of clusters, so as to drive industrial upgrading. However, at the same time, financial risks in industrial clusters also increase with the clustering of enterprises. Once some enterprises have financing problems, domino effect will easily appear and affect the upstream and downstream enterprises.

\subsection{Structure upgrade effect}

The rapidly expanding domestic market and rapid economic development of emerging economies provide opportunities and space for their industries and enterprises to move to the higher end of the global value chain and carry out transformation and upgrading. At present, emerging economies achieve industrial upgrading mainly through the following means: cultivating brands through the market, cultivating technologies through the market, accumulating the funds needed for transformation, interacting with domestic and foreign markets and complementing each other's advantages. In addition, " One Belt and One Road " put forward by the general secretary of the construction provides a foreign investment opportunity, also increased the size of foreign investment, which can be of more resources from industry, instead of into the advantages of industry, adjust and upgrade the industrial structure, in order to promote international status for China's industrial upgrading, change peers provides a good opportunity. Now, "One Belt and One Road" has promoted the further expansion of the international circulation of RMB. By 2017, the People's Bank of China has signed bilateral currency swap agreements with the central Banks (monetary authorities) of 36 countries or regions, with a quota of over 3.3 trillion RMB.

However, except a few countries such as China, India and Russia, almost all countries along the "One Belt and One Road" are basically small countries with low economic development level, large currency fluctuations and exchange rate risks. In addition, due to the poor ability of these countries to resist foreign financial risks, their financial markets are easily affected by the economic fluctuations of other countries and produce frequent fluctuations. Finally, due to the imperfection of these countries' financial markets, they are easy to become the speculation target of international liquidity and are more vulnerable to the attack of foreign exchange arbitrage, which exposes transnational corporations to high financial risks. In addition, many countries along the "One Belt and One Road" have high proportion of non-performing loans and large exchange rate fluctuations. For example, in 2014, countries with a non-performing loan ratio higher than the internationally accepted safety standard accounted for more than half of the total number of countries along the belt and road. In Kazakhstan, Tajikistan, Yemen and other countries, the non-performing loan ratio of Banks exceeded 20\%, further expanding the financial risk.

\section{Characteristics of Division of Labor Transfer of Manufacturing Industry Under the Background of Global Value Chain Reconstruction}

\subsection{Trans fer of industrial division of labor to product division of labor}

The rapid development of logistics industry reduces the cost of transportation, while the integration of global trade reduces the cost of cross-border trade and promotes the decentralization of international production. International division of labor has experienced from industry division, industry division of labor between the development of the latest products in form of labor division, the division of labor in manufacturing process level, a product of the production of different processes across different countries and regions, countries are more detailed and specialized production, achieve efficient allocation of global resources 
utilization. Different countries in the world undertake different production links of products through division of labor, and the production process of the whole product is divided. In the process, is the dominant force in a multinational company, multinational company with branches all over the world, the product distribution of production activities to countries or regions with different comparative advantages, in the process, the same product may face many import and export situation, tariff, exchange rate and import and export of speed, the host country policy became the important risk factors influencing the product price.

Products import and export of speed will influence the transnational capital chain problems, some countries like Kazakhstan, Uzbekistan, Tajikistan, Kyrgyzstan and so on, import and export to file has reached as many as dozens of complete export formalities need time for months, bring huge uncertainty to multinational companies. Policy changes in the host country are also likely to lead to the increase of production costs of subsidiaries, such as the introduction of regulations on employment restrictions of management personneland limits on the proportion of domestic employees, which are likely to bring losses to enterprises. What's more, some countries use confiscation, expropriation and other means to directly take possession of enterprises, so that multinational companies cannot effectively control, deal with and use their legal property.

\subsection{Characteristics of adjustment and transfer of process links within the product}

Intra-product division of labor and global value chain are mutually integrated and mutually supported. A country's position in participating in intra-product division of labor is closely related to its ability to obtain high and low added value in the value-added link of global value chain. The high-end position of the division of labor within the product corresponds to the links with high added value in the value chain. The low-end position of product division corresponds to the links with low added value in the value chain and the corresponding industrial development level is also low. At the beginning of the Reform and Opening up, China entered the global value chain through the comparative advantage of labor-intensive industries and specialized production of capital-intensive products with comparative advantage. Key parts of many industries are controlled by companies in developed countries, and China is in the middle of the smile curve, earning only modest returns. Long learning process, part of the industry in China completed the accumulation of capital and technology accumulation, improve their innovation ability, through the research and development, to achieve "technological leapfrogging" on materials, process, or for the key parts of a breakthrough, central business activities by the smile curve of manufacturing of the key parts of the upper left, mobile development steps, to achieve industrial upgrading.

In order to break through the restriction of core technology, realize the self-production of core key parts and components, and break the upstream technology monopoly, the enterprise mainly has the following two measures: carry out merger and acquisition in the technical field, acquire strategic resources, and realize the enterprise leapfrog and upgrade; Focus on research and development to achieve core technology breakthroughs. In the process of implementing strategic M\&A, enterprises are likely to face the break of capital chain, while R\&D means long-term, continuous and high proportion of capital investment, which increases the risks of enterprises.

\subsection{The production link is transferred to the $R \& D$ design and brand marketing link}

The value chain is composed of a series of links, including product design, research and development, production, marketing and recycling. Link with high added value such as design, research and development, logistics, marketing and after-sales service of added value is much higher than production processing link, therefore, many companies begin to extend from manufacturing to production services, increasing investment, business activities from the central part of the smile curve to upper mobile marketing, after-sale service, realize the value-added and industry upgrade. In the process of transferring the production link to the $R \& D$ design and brand marketing link, many multinational enterprises have realized the transformation from manufacturer to solution provider. With the continuous development of the enterprise upstream and downstream and the continuous improvement of the product structure, the company has gradually transformed itself into an 
integrated solution provider of industrial equipment for customers, and started to develop products and services according to the needs of specific industries and customers. However, in the process of expanding the market, high operating costs are often required for a long period of time, and several projects are often carried out at the same time. Once the market expansion hits a bottleneck, difficult recovery of funds will lead to the regression of enterprise development process, but also may cause enterprises to miss vertical development, from the technical breakthrough and upgrade opportunities.

\subsection{The production link is transferred to the R\&D design and brand marketing link}

The value chain is composed of a series of links, including product design, research and development, production, marketing and recycling. Link with high added value such as design, research and development, logistics, marketing and after-sales service of added value is much higher than production processing link, therefore, many companies begin to extend from manufacturing to production services, increasing investment, business activities from the central part of the smile curve to upper mobile marketing, after-sale service, realize the value-added and industry upgrade. In the process of transferring the production link to the R\&D design and brand marketing link, many multinational enterprises have realized the transformation from manufacturer to solution provider. With the continuous development of the enterprise upstream and downstream and the continuous improvement of the product structure, the company has gradually transformed itself into an integrated solution provider of industrial equipment for customers, and started to develop products and services according to the needs of specific industries and customers. However, in the process of expanding the market, high operating costs are often required for a long period of time, and several projects are often carried out at the same time. Once the market expansion hits a bottleneck, difficult recovery of funds will lead to the regression of enterprise development process, but also may cause enterprises to miss vertical development, from the technical breakthrough and upgrade opportunities.

\section{Characteristics of Capital Flow Transfer in Manufacturing Industry Under the Background of Global Value Chain Reconstruction}

\subsection{Mutual investment among developed countries}

The mutual convection of capital between America, Japan and Europe is still the mainstream of international capital movement in the present and future period. From the perspective of the relative relationship between the status of international investment between the United States, Japan and the EU, the United States is still one of the countries that carry out and attract the most OFDI in the world, and the United States will still be the main driving force for world economic development. In the OFDI of the United States to the European Union, the manufacturing industry has maintained a relatively stable investment proportion, about $20 \%$ every year from 1998 to 2003.EU investment in the US is concentrated in manufacturing, wholesale commerce and finance. According to the 2017 world investment report, global foreign direct investment flows fell by $2 \%$ to $\$ 1.75$ trillion in 2016.FDI into developed economies -- global foreign direct investment -- rose 5\% to $\$ 1.032 \mathrm{tn}$. The US topped the list with $\$ 391$ billion in foreign direct investment. In 2017, FDI flows to developed countries totally as $\$ 712$ billion. US FDI inflows fell $40 \%$ to $\$ 275 \mathrm{bn}$, but remained the world's largest. FDI into the UK fell $92 \%$ to $\$ 15 \mathrm{bn}$, falling out of the top 20.FDI inflows into France and Germany rose, but flows into Europe fell as a whole, dragged down by the UK. 
Table 1. The world's top 10 FDI destinations in 2016[ Hundred million \$]

\begin{tabular}{|l|l|l|l|}
\hline Ranking & countries & Inflows in 2016 & Inflows in 2015 \\
\hline 1 & The United States & 3911 & 3484 \\
\hline 2 & The British & 2538.3 & 330 \\
\hline 3 & China & 1337 & 1356.1 \\
\hline 4 & Hong Kong, China & 1081.3 & 1743.5 \\
\hline 5 & In the Netherlands & 919.6 & 687.5 \\
\hline 6 & Singapore & 616 & 705.8 \\
\hline 7 & Brazil & 586.8 & 642.7 \\
\hline 8 & Australia & 481.9 & 194.8 \\
\hline 9 & India & 444.9 & 440.6 \\
\hline 10 & Russia & 376.7 & 118.6 \\
\hline
\end{tabular}

\subsection{Mutual investment among developing countries}

By the end of 2015, China's stock of direct investment in developing countries accounted for $86 \%$ of the total, with a total investment of us $\$ 9441.59$. In 2015, China's stock of direct investment in developing countries was us $\$ 458.81$ billion, double that of 2012. China's stock of OFDI to the Russian federation was $\$ 14.02$ billion, accounting for $1.3 \%$ of the total, while China's stock of OFDI to Indonesia was $\$ 8.125$ billion, accounting for $0.7 \%$ of the total. By the end of 2016, China's OFDI stock had reached us $\$ 1,357.4$ billion, $84.2 \%$ of which were distributed in developing economies. In 2018, the new version of the special administrative measures on access to foreign investment (negative list) will significantly expand market access, covering areas such as finance, transportation, trade flows, professional services, manufacturing, infrastructure, energy, resources and agriculture, and adopt a series of measures to improve the business environment. During the first ten months of this year, China's actual foreign investment reached 107.66 billion\$, up $6.5 \%$. The investment from South Korea increased by $36 \%$, the investment from Japan increased by $24 \%$, the investment from the United Kingdom increased by $176 \%$, and the investment from the United States increased by $7 \%$ to 3.02 billion\$. In 2018, China became the world's largest recipient of foreign direct investment.

\subsection{Investment from developed and developing countries}

In order to change the development mode of enterprises and break the low-end lock of the value chain, with the internal motivation of factor drive, market drive, resource drive and strategic asset drive, the developing countries led by China began to invest in some industries of developed countries and expand the international market. According to the world investment report, FDI inflows into the developing world fell $14 \%$ to $\$ 646$ billion in the year to 2016 .FDI from developing economies remained stable at $\$ 383$ billion. In terms of volume, the relative position of China's manufacturing industry and that of the United States is basically stable, and the total share of China and the United States in the world is still rising rapidly. The global manufacturing value chain is expected to be dominated by the us and China for some time to come.

Table 2. Basic situation of foreign economy and trade [Hundred million RMB]

\begin{tabular}{|l|l|l|l|l|l|}
\hline \multicolumn{1}{|c|}{ Indicators } & \multicolumn{1}{c|}{2013} & \multicolumn{1}{c|}{2014} & \multicolumn{1}{c|}{2015} & \multicolumn{1}{c|}{2016} & \multicolumn{1}{c|}{2017} \\
\hline Import and export of goods & 258168.9 & 264241.8 & 245502.9 & 243386.5 & 278101 \\
\hline Total exports & 137131.4 & 143883.8 & 141166.8 & 138419.9 & 153311.2 \\
\hline Total imports & 121037.5 & 120358 & 104336.1 & 104967.2 & 124789.8 \\
\hline Import and export balance & 16094 & 23525.7 & 36830.7 & 33452.1 & 28521.4 \\
\hline $\begin{array}{l}\text { Total import and export of } \\
\text { goods (US \$) }\end{array}$ & 41589.9 & 43015.3 & 39530.3 & 36855.6 & 41071.6 \\
\hline
\end{tabular}


Trade frictions between China and the US continued to escalate in 2018 and the number of mergers and acquisitions by Chinese companies in the US has dropped significantly. Chinese direct investment in the United States dropped 83 \%to \$4.8 billion in 2018 from \$29 billion in 2017 become the lowest level since 2013. On August 13, 2018, the President of the United States signed the national defense authorization act for fiscal year 2019, which expanded the scope of transactions under the jurisdiction and increased the consideration of review factors. The trend of tightening investment review is obvious, especially increasing the review of investment from China. For the high-tech industry favored by Chinese enterprises, the probability of the approval is higher. In order to reduce the trouble, American sellers prefer domestic buyers and frustrated Chinese investors turn to Europe and countries along the "One Belt and One Road". At the end of 2018, Chinese enterprises had made us $\$ 15.64$ billion of non-financial direct investment in 56 countries along the belt and road. The amount of overseas M\&A of Chinese enterprises in Europe increased rapidly, up to $37.96 \%$, with a total amount of 65.94 billion US dollars, making it the region with the largest M\&A amount of Chinese enterprises. Portugal, Spain and Germany were the most popular destinations.

In 2018, China's outbound investment mainly went to leasing and business services, manufacturing, wholesale and retail, mining and other industries, accounting for $37 \%, 15.6 \%, 8.8 \%$ and $7.7 \%$ respectively, among which the outbound direct investment to the tertiary industry was 84.25 billion\$, up $3.6 \%$ year-on-year, accounting for $69.9 \%$. The significant expansion of the proportion of tertiary industry investment shows that China's tertiary industry, which mainly focuses on finance, insurance, information and commodity retail, is gradually entering the mainstream industry of international mergers and acquisitions.

Foreign investment enterprises, on the one hand, can transfer the excess capacity, transfer resources more to those with high value-added and high technology content industry, and promote the optimization of industrial structure in our country, make it more uniform stability, on the other hand also can be realized through the investment of foreign enterprises transnational mergers and acquisitions to gain advanced technology resources in host countries. Overseas M\&A is the most important method to our country enterprise overseas investment, but the Chinese enterprise's relative lack of talent in this aspect, in the process of overseas M\&A, tend to trade more to agency solely for preliminary communication, from the merger deal such, so operation is of course a shortcut, but which also contains a huge risk, relying too much on intermediaries caused by information asymmetry, easy to cause merger failures.

\section{Summary and Suggestions}

In the context of global value chain reconstruction, the factors influencing the overseas investment and operation activities of manufacturing multinational enterprises are increasingly complex. Therefore, we suggest that multinational enterprises construct a complete risk control system for overseas investment and operation. At same time, in order to move China's manufacturing industry to the high value-added end of the value chain, enterprises should timely grasp the opportunity in overseas business and investment activities to acquire foreign complementary assets needed for the development of the high-end value chain.

\section{Acknowledgment}

This call of paper is supported by "the Fundamental Research Funds for the Central Universities" (2018VI002).

\section{References}

[1] Wen Zha, Xiang Li. Change of leadership group and adjustment of foreign policy [J]. World economy and politics, 2018(01):53-72+157-158. 
[2] Yuesheng Wang. The world economy may enter the era of multi-trend coexistence: characterization, causes and future -- also on trump's "three zero trade order" [J]. International economic review,2018(06):129-142+8.

[3] Kan Zhang. Research on global value chain upgrading of China's manufacturing industry based on financial development [D]. Beijing Jiaotong university,2016.

[4] Peizhe Shi. A study on the positioning of enterprise clusters in the global value chain division of labor system [D]. Beijing Jiaotong university,2012.

[5] Weiping Liu. Research on industrial chain control of Chinese enterprises in global value chain division [D]. Jiangxi university of finance and economics,2009.

[6] Liwan Huang. Study on internationalization of China's labor-intensive industrial clusters under global value chain [D]. Anhui university of finance and economics, 2014. 